\title{
LETS
}

Journal of Linguistics and English Teaching Studies

ISSN (print) : 2715-4408

ISSN (online) : 2715-4416

Homepage : https://jurnal.stainmajene.ac.id/index.php/lets/

\section{The Students' Skill in Performing A Speech in SMA Negeri 6 Pinrang}

\author{
Haslinda ${ }^{1}$, Mujahidah ${ }^{2}$, Nurhamdah ${ }^{3}$ \\ IAIN Parepare \\ lyyat98@gmail.com ${ }^{1}$, mujahidah@iainpare.ac.id ${ }^{2}$,nurhamdah@iainpare.ac.id ${ }^{3}$
}

\begin{abstract}
The aims from this research are to know how is students' skill in performing a speech, and to know the students' deprivation in performing a speech. This research is mix method design to answer the problem of this thesis. The research took place at SMA N 6 Pinrang. The population was the students from eleventh grade, the sample of this research were 34 students who are from class XI MIPA 1 by used purposive sampling technique. The researcher used test and interview as instrument for this research. The speech performance used manuscript speech delivery method. The results of this research find that the students' skill in performing speech are not fully fill up with the criteria of assessment, where the mean score from the performance is 189.79. Additionally, in analyzing the interview, the researchers conclude that there are some deprivations when the students perform their speech, the factors that been found over the interview were the use of English as a language used it selves in performing a speech. Moreover, the use of vocal variety and physical movement also mentioned with the students as their deprivation in performing a speech.
\end{abstract}

Keywords: Speech, Extensive Speaking, CLT

\section{Introduction}

As English is thought of the international language and it is spoken all over the world, it serves the aim of human action with the people who live in totally different regions, states, countries, and continents of the world. Where English is growing and taking place under half of the aspect in our life and society, as English is wide used everywhere in the world, there is a requirement for learners to accumulate the communication skills to urged success in their various fields.

The students were expected to be able in English used as one of the parts of language that used in worldwide or in the international relationship. Speaking becomes one of the important skills from English, as oral communication it was seen as the use of language fluency developing in process by involving functional and social dimensions. Classroom could become one of the first places that bring the experiences to the students to developing their skill in speaking. As we know, speaking is the act of saying something in oral and it was containing with grammar, vocabulary, pronunciation as the language system and as well as cultural awareness in a spoken discourse.

In speaking skill there are five basic styles. They are imitative, intensive, responsive, interactive, and extensive, based on fifth style of speaking the researcher solely centered on extensive speaking. Where it was type of speaking that concern on oral productions, include speeches, oral presentation, and story telling.

Having skill to deliver or perform a speech in front of a group of people and compare with their competence in learning English as a second language and the students need to improve the language that they have been learnt, seems really needed. Especially, 
mastering speaking skill in order to do communication with the others and public speaking is a place to help students enhance their speaking skill. That is to say, the students should not only be equipped with language knowledge, but also be capable of appropriately using the foreign language in various situations.

Cite from Larry King's book, that performing a speech or be a public speaker is the same things with another types of conversation. It comes with a purpose to deliver thought to the audience. In some aspect, speech is easier than conversation, because you control the entirely way of speech. Nevertheless, you must have something clearly to say and there is no evade like on the simple conversation. In another explanation performing a speech is a form of expression you have to do it about a topic and whatever that topic it defines you better than the actual speaking. Have a same meaning with speaking as performance. Richards on A. Kaharuddin books explain that speaking as performance is recognized as the third type of speaking which refers to public speaking, that is, speaking type that transmits information in front of an audience, such as classroom presentations, public announcement, lecture as well as speeches.

When you deliver a speech, people merge its verbal and visual components into a presentation before an audience. There are four types of delivery methods: impromptu, extemporaneous, manuscript, and memorized. In public speaking, the delivery of speech either little or no preparation is called impromptu speech. Impromptu speech is a type of delivery where is unpracticed, spontaneous, or improvised, involving speaking on relatively short notice with little time to prepare. Many occasions suppose you to make some remakes on the spur of the moment, and it is given a topic on the spot and often has some minuets to think about to say.

Extemporaneous speech has a meaning to speak from limited notes. It falls somewhere between impromptu and written or memorized deliveries. On this method, you prepare well and practice in advance, giving full attention to all facets of the speech, such as content, arrangement, and delivery alike, instead of that you speak based on outline of key words and phrases, having concentrated throughout your preparation and practice on the ideas that you want to deliver.

Manuscript speech means you read a speech, that is, from written text that contains the entire speech, word for word. As a rule, speech from manuscript restricts eye contact and body movement, and may also limit your expression in vocal variety and quality. The formal name from memorized speech is oratory. When memorized speech is delivering, the speaker commits the entire speech with memorizing and then presents it to an audience. Memorized speech can use in for short speeches, such as wedding toast or acceptance of an award. Knowing exactly the word you want to say reduce your to not sound unprepared or make comments your regret later. However, memorizing an entire lengthy speech can cause several problems, first, forget a line or a word.

In this case, the scope of this research was limited only for the students' skill in performing a speech, where the students used manuscript speech method to deliver their speech.

\section{Method}

This research is mix method which would consist with quantitative and qualitative. Since the researcher needs to describe the results and the findings and show a range of number from the students' score after performing a speech. It based on the aim of this 
research to know how the students' skill in performing a speech and the researcher also needs to know what the students' deprivation in performing a speech.

The population of this research is whole students at the eleventh grade of SMAN 6 Pinrang, in academic year 2020/2021. Total populations are 123 students.

Table1. The Population of the eleventh-grade students of SMAN 6 Pinrang

\begin{tabular}{lllll}
\multirow{2}{*}{ No } & Class & \multicolumn{2}{c}{ Students } & \multirow{2}{*}{ Total } \\
\cline { 3 - 4 } & Male & Female & \\
\hline 1 & XI MIPA 1 & 11 & 23 & 34 \\
2 & XI MIPA 2 & 12 & 22 & 34 \\
3 & XI IPS 1 & 15 & 15 & 30 \\
4 & XI IPS 2 & 12 & 13 & 25 \\
& Total & 50 & 73 & 123 \\
\hline
\end{tabular}

For four classes of eleventh grade on SMAN 6 Pinrang program academic year 2020/2021 as the population, the researcher took class XI MIPA 1 as sample and used probability sampling which is would use purposive sampling as the technique of sampling. It is based on the research purpose to give a test to students that have been learning using CLT.

To find out students' skill in performing a speech the researcher gave a test to the students by asking them to performing a speech and to supports the result of this research, the researcher also doing an interview to help researcher to know the students' deprivation in performing a speech.

In collecting the data, the researcher used some ways as follow: (1) The researcher sent the instrument test to the students, which consist of instruction and instrument test. (2) The students submit their speech performance in video format. (3) After the test is finish, the researcher collected the results of the students' test. (4) Then, the researcher doing an interview to the students about their deprivation in performing a speech. (5) The researcher got a conclusion based on the test results and the interview.

\section{Results}

\subsection{Findings}

Since the researcher adopted the public speaking competencies and criteria form assessment from national communication association (NCA), the researcher also used the scoring technique based on national communication (NCA) to showing the range of grade from the students' performance. In this case, the range of grade from the speech would be 8 to 24. The particular reason for circumstance, the researcher was assigned one point for unsatisfactory, two points for satisfactory, and three points for excellent. After that the researcher would multiply the basic score of the speech (ranging 8 to 24) by any number to increase the total value of the speech.

To know the students' grade, the researcher used the following table which consisted of students' grade. 
Table 2. The students' grade in Performing a Speech

\begin{tabular}{llll} 
No & Grade & Frequency & Mean \\
\hline 1 & 275 & 2 & 16.17 \\
2 & 262 & 1 & 7.7 \\
3 & 250 & 2 & 14.7 \\
4 & 237 & 2 & 13.94 \\
5 & 225 & 1 & 6.61 \\
6 & 212 & 2 & 12.47 \\
7 & 200 & 4 & 23.57 \\
8 & 187 & 2 & 11 \\
9 & 175 & 5 & 25.73 \\
10 & 162 & 7 & 33.35 \\
11 & 150 & 3 & 13.23 \\
12 & 137 & 1 & 4.02 \\
13 & 125 & 2 & 7.35 \\
Total & & 34 & 189.79 \\
\hline
\end{tabular}

All of the grade that have been submitted is gotten from eight competencies which consisted with three level of performance (unsatisfactory got 1 point, satisfactory got two points, excellent got three points) after the students got their basic points it would multiply with number of 100 , then divide it to 8 . It has been done to increase the value from the students' performance in performing speech, to sum up everything that had been stated so far from this section the mean grade was 189.79 .

From the table above showed 34 students have done the speech performance, based on the data, 275 became the highest grade from this evaluation and 125 is the lowest grade from this evaluation, through the grade that the students get, here is the finding about the students' competences in performing a speech where been found by the researcher.

\subsection{Discussion}

\subsubsection{The Students' Skill in Performing a Speech}

Making a speech or being a public speaker is the same for other types of conversation. It serves to convey the idea to the audience. In some ways, speaking is easier than conversation because you have complete control over the way you speak. You have to have something clear to say and there is no way to evade it like a simple conversation. Communicative Language Teaching (CLT), as it is known as the Communicative Approach, is part of the theory of language as Communication, focuses on the meaning of communication, not structure, use not usage. The communicative approach focuses on how to communicate language. Moreover, the chosen of the students that been taught in CLT approach being a sample on this research did not make the assessment to be faded, this research meant to know the students' skill in performing a speech. 
The students' skill in performing a speech was evaluated through eight competences that had been adopted from National Communication Association (NCA), where the competences divide into three different levels of performances (excellent, satisfactory, unsatisfactory). The results of the research questions could be seen at the research finding above. After the data was presented then those are discussion on this part.

Based on the data above showed there are some competences that hit a lot of differences between the excellent, satisfactory, and unsatisfactory, the students got unsatisfactory the most on competence three (provides supporting material, including electronic and non-electronic presentational aids that appropriate to the audience and occasion). On this competence the students use supporting material that is inappropriate in quality and variety since the students using manuscript speech delivery method the students seems did not know how to improve their material or they did not what should to do with it. For thirty-four students at least one (student 25) of them using supporting material that is appropriate in quality and variety, that is suitable with her topic which is talk about "should mobile phone be banned from school?", the next competence that hit a lot of differences between the excellent, satisfactory, and unsatisfactory was competence seven where a lot of students fail to use acceptable articulation, pronunciation, and grammar.

And for competence four (uses an organization pattern appropriate to the topic, audience, occasion and purpose) a lot of students uses an exceptional introduction and conclusion and provides an exceptionally clear and logical progression within and between ideas. That is to say, mostly students have been known how to make speech within an organization pattern.

Based on the analysis of data, that is to say, the researcher makes conclusion whether the students' skill in performing a speech for the communicative language teaching (CLT) class are not fully fill up with the criteria of assessment and that is to say, mostly students at eleventh grade of SMA N 6 Pinrang presented a topic and focus that are appropriate for purpose to the audience with manner that is adequately clear and identifiable, but the students did not used supporting material that is appropriate in quality and variety, while they used an exceptional introduction and conclusion on their speech, and the students also used language that is reasonably clear, vivid and appropriate to the audience, also for the vocal variety some students makes exceptional and acceptable use. In another competences the students fails to use acceptable articulation, pronunciation and grammar, the students also fails to use acceptable posture, gesture, facial expression and eye contact.

\subsubsection{The Students' Deprivation in Performing a Speech}

Performing a speech may hard to do for some people and the fear of public speaking may become obstacles that have to face when deliver or perform a speech. The fear may appear on the range of physical reaction such as pounding hearts, dry mouth, shaky hands and others. Meanwhile, fear is normal reaction to public speaking and also become a boost to our performance. ${ }^{1}$

Data collected from the students' interview showed their deprivation in performing a speech, and based from the interview the researcher found if the students really aware with their performance while their feel afraid and worry at the same time, it proved with the questions what the students feel before and after doing speech performance, mostly students' answer their feel nervous before doing the performance but they did not described

${ }^{1}$ Ariana Nikita, Successful Public Speaking (Russia: Acadimic Transer, 2011), p. 16. 
it more, is it there a physical symptom or not, and after doing the performance most of the students answer they feel relieved, and some students answer they feel happy after doing speech, and for their performance mostly the students did not feel confident if they doing it well because they worry with language used. That is to say, language used became the biggest deprivation that had been found during the interview, this matter includes the capability to speak in English, the feeling if they did not fluent in English, the pronunciation matters and feel strange with English. Another deprivation that found were choosing the material for the speech, also the students mention if nervous became their deprivation and make them blank and forget their speech, also the used of vocal variety, pitch and intensity, and the physical movement.

In addition, when they had been asked about the importance of speech the students give an appreciative respond with the question, they really aware how related and important it was for their social environment or as a student, and how it really needed to supported them in next level of their degree.

All of those difficulties or students' deprivation are hampered the students in performing speech. Each of the students has their own deprivation, there are students that still struggle with the use of English as the language used in performing speech and it force them to speak in English while they feel it really weird to heard their selves speaking in English, and some of them did not feel confident with that. And it also same with the used of vocal variety, most of the students ignore their pitch and intensity, they only focus on the language used, like the pronunciation, only few of them mention about the vocal variety and the physical movement as the difficulties.

\section{Conclusion}

Thirty-four students have been performing a speech by using manuscript speech delivery method and the total mean score from the performance is 189.79. the student's speech competencies were adopted from National Communication Association (NAC), the competent speaker speech evaluation was divided into eight competences with three different level (excellent, satisfactory, unsatisfactory). Based on the analysis of data, the researcher makes conclusion whether the students' skill in performing a speech for the communicative language teaching (CLT) class are not fully fill up with the criteria of assessment and that is to say, mostly students at eleventh grade of SMA N Pinrang presented a topic and focus that are appropriate for purpose to the audience with manner that is adequately clear and identifiable, but the students did not used supporting material that is appropriate in quality and variety, while they used an exceptional introduction and conclusion on their speech, and the students also used language that is reasonably clear, vivid and appropriate to the audience, also for the vocal variety some students makes exceptional and acceptable use. In another competences the students fail to use acceptable articulation, pronunciation and grammar, students also fail to use acceptable posture, gesture, facial expression and eye contact.

It was found if the students' deprivation were their capability in English, it selves, this matter include the capability to speak in English, the feeling if they did not fluent in English, the pronunciation matters and feel strange with English. The next matter is the vocal variety, includes the pitch and intensity and also their physical behavior, another deprivation that found were choosing the material for the speech, also the students mention if nervous became their deprivation and make them blank and forget their speech. 


\section{References}

Akib, Hilmiyah. (2017). Improve Students' Skill In Performing a Speech Through Contextual Teaching Learning (CTL) at the Twelfth Grade of MAN 2 Parepare. Skripsi: English Program of Tarbiyah and Adab Departement State Islamic Collage (STAIN) PAREPARE.

Arikunto. (2010). Prosedur Penelitian: Suatu Pendekatan Praktek, Fourteenth edition. Jakarta: PT Rineka Cipta.

Bahar, A. kaharuddin. (2014). Interactional speaking. Yogyakarta: Trustmedia Publisher.

Bahar, A. Kaharuddin. (2013). The Communicative Competence Based English Language Teaching. Yogyakarta: TrustMedia Pubisher.

Bahar, A. Kaharuddin. (2014). Transactional Speaking, A Guide To Improve Transactional Exchange Skills in English For Group Discussion (GD) And Interviews. Gowa: Gunadarma IImu.

Berkun, Scott. (2010). Conffension of A Public Speaker. Canada: O'reilly Media Publisher.

Brown, H. Douglas. (2004).Language Assessment, Principles and Classroom Practices. USA: Longman.

Coopman, Stephanie J. and James Lull. (2012). Public Speaking: The Evolving Art, Second Edition.USA: Cengage Learning publisher.

Gay, L. R. (1981). Educatioal Research Competencies for Analysis and Applications, Second Edition. Columbus Ohio: Person Merrill Prentice Hall.

G, Jin. (2008). Application of Communicative Approach in Collage English teaching. Vol.4 No.4.

Hair, Dan. O. (2009). A Pocket guide to Public Speaking.Boston: Quebecor World Eusey Press.

Harris, Leslie. J. (2017). Stand up, speak out: The Practice and Ethics of Public Speaking.USA: University of Minnesota Library Publishing.

Ho Wah Kam, R. Y. (2004). English Language Teaching in East Asia Today,Second Edition. Singapore: Marshall Cavendish International.

Jabeen, Shazi. Shah. (2014). Implementation of Communicative Approach (English Language Teaching). Vol.7 No.8.

King, Larry. (2007). Seni Berbicara Kepada siapa Saja, Kapan Saja, Dimana Saja. Jakarta: PT Centro inti Media Publisher.

Morreale, Sherwyn, et al. (2007) The Competent Speaker Speech Evaluation Form, Second Edition. Washington:National Communication Association.

Nikitina, A. (2011). Successful Public Speaking.Russia: Academic Transfer.

Olif. (2018). Lancar Berbicara. Yogyakarta: Komunika publisher.

Paradewari, Dirtya, S. (2017). Investigating Students' Self-efficiency of Public Speaking, International Journal of Education and Research. vol.5 No.10.

Rao, parupalli Srinivas. 2013. The Importance of Speaking Skills in English Classrooms, Alforld Council of International English \& Journal (ACEIL). Vol. 2. No.2. 
Richards, Jack C. and Theodore S. Rodgers. (1995). Approaches and Methods in Language Teaching, Eleventh printing. USA: Cambridge University Press.

Shih-Chuan Chang. V. (2011). A contractive study of grammar translation and communicative approach in teaching English grammar. Vol.4 No.2.

Thamarana, Simhachalam. (2015). A critical Overview of Communicative Language Teaching. Vol 3. Issue V.

Vanessa, et al. (2019). The Use of the Communicative Language Teaching Approach to Improve Students' Oral Skills, English Language Teaching. Vol. 12. No. 1.

Whitman, Richard F. (1983). Speech Communication, principle and Contexts. New York: Macmillan Publishing.

Yasin, Burhanuddin, et al. (2017). Communicative Language Teaching (CLT) for Teaching Speaking, English Education Journal. Vol. 8, No.3. 